\title{
Effects of Different Feeding Frequencies on Growth Performance and Feed Consumption in Juvenile Turbot (Scophthalmus maximus Linnaeus, 1758)
}

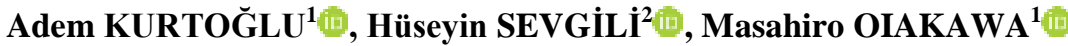 \\ ${ }^{1}$ Mediterranean Fisheries Research Production and Training Institute, Beymelek Unit, Demre, Antalya, Turkey. \\ ${ }^{2}$ Mediterranean Fisheries Research Production and Training Institute, Kepez Unit, Döşemealtı, Antalya, Turkey.
}

Corresponding Author: husevgili@yahoo.com

Received 14 March 2019; Accepted 09 August 2019; Release date 15 September 2019.

How to Cite: Kurtoğlu, A., Sevgili, H., \& Oiakawa, M. (2019). Effects of different feeding frequencies on growth performance and feed consumption in juvenile turbot (Scophthalmus maximus Linnaeus, 1758). Acta Aquatica Turcica, 15(3), 404-410. https://doi.org/10.22392/actaquatr.540268

\begin{abstract}
This experiment aimed to determine the effects of feeding frequencies on growth, feed intake and feed conversion efficiency in turbot, (Scophthalmus maximus Linnaeus, 1758). Six treatments consisted of feeding twice a day for 6 and 7 days a week $\left(6: 1_{(2)}\right.$ and $7: 0_{(2)}$ respectively), feeding twice a day and then one or two days starvation $\left(1: 1_{(2)}\right.$ and $1: 2_{(2)}$ respectively), two days feeding and one day starvation $\left(2: 1_{(2)}\right)$ and feeding once a day for six days a week $\left(6: 1_{(1)}\right)$. Initial average weight of fish was $110.3 \pm 0.5 \mathrm{~g}$. They were fed until apparent satiation in each meal regardless of the treatments for 6 weeks. Each treatment was tried in triplicate tanks. At the end of the experiment, fish particularly those on $7: 0_{(2)}$ and $6: 1_{(2)}$ performed significantly better than those on $1: 2_{(2)}(p<0.05)$ in terms of daily growth coefficient. The differences in growth rate actually were a reflection, at large extend, of amount of food consumed. Briefly fish fed more frequently consumed more feed and individuals on 7:0, $0_{(2)}, 6: 1_{(2)}$ and $2: 1_{(2)}$ had significantly higher feed intake than those on $1: 2_{(2)}$. On the other hand, feed intake per feeding day or per meal were inversely related with feeding days $\left(n=18, r^{2}=0.89\right)$ and number of meals $\left(n=18, r^{2}=0.87\right)$. Feed conversion efficiency was not affected by the treatments. A quadratic broken line model estimated minimum number of daily meal for maximum growth as 1.756, equal to twice a day feeding for 6 days a week.
\end{abstract}

Keywords: Turbot, feeding frequency, meal size, feed consumption.

Farklı Yemleme Sıklıklarının Yavru Kalkan (Scophthalmus maximus Linnaeus, 1758)'da Büyüme Performansı ve Yem Tüketimine Etkileri

Özet

$\mathrm{Bu}$ araștırma farklı yemleme sıklıklarının yavru kalkan (Scophthalmus maximus Linnaeus, 1758)'da büyüme, yem tüketimi ve yemden yararlanma oranına etkilerini belirlemek amacıyla yürütülmüsşür. Altı muamele, haftada 6 veya 7 gün ikişer ögün (sırasıyla 6:1 $1_{(2)}$ ve 7:0 $0_{(2)}$ ), bir gün ikişer öğün yemleme ve ardından bir veya iki gün aç bırakma (sırasıyla $1: 1_{(2)}$ ve $\left.1: 2_{(2)}\right)$, iki gün çift öğün yemleme bir gün aç bırakma $\left(2: 1_{(2)}\right)$ ve haftada altı gün tek öğün $\left(6: 1_{(1)}\right)$ şeklinde olmuştur. Başlangıç ağırlığı $110.3 \pm 0,5 \mathrm{~g}$ olan balıklar her öğünde doyuncaya kadar yemlenmiştir. Her bir muamele üç tekerrürlü olarak test edilmiştir. Deneme sonunda 7:0 $0_{(2)}$ ve 6:1 $1_{(2)}$ muamelelerindeki balıklar 1:2(2) 'dekilerden önemli derecede daha yüksek büyüme oranı göstermiştir $(\mathrm{p}<0,05)$. Büyüme hızında gözlenen bu farklılıklar, tüketilen yem miktarının bir yansıması sonucu olmuștur. Daha sik beslenen balıklar toplamda daha fazla yem tüketmișler ve $7: 0_{(2)}, 6: 1_{(2)}$ ve $2: 1_{(2)}$ 'deki bireyler $1: 2_{(2)}$ 'dekilere göre önemli derecede daha fazla tüketmişlerdir $(\mathrm{p}<0,05)$. Buna zit olarak, günlük yem tüketimi veya öğün başına yem tüketimi yemleme günü ile zıt bir ilişki göstermiştir (sırasıyla, $n=18, r^{2}=0,89$ ve $n=18, r^{2}=0,87$ ). Yemden yararlanma etkinliği muamelelerden etkilenmemiştir. Maksimum büyüme için gerekli minimum ögün sayısı kuadratik kırık modeli ile 1,756 olarak tahmin edilmiş ve bu da aşağı yukarı hafta 6 gün çift öğünlü uygulamaya eşit bulunmuştur.

Anahtar kelimeler: Kalkan, yemleme sıklığı, öğün büyüklüğü, yem tüketimi. 


\section{INTRODUCTION}

Optimization of feeding levels and frequencies in aquaculture farms is of great importance in terms of meeting nutritional requirements of fish, farm management, environmental impacts, labor and feeding associated costs. Feed can be delivered at either ad libitum or satiation level or a restricted level close to satiation point during varying stages of fish (Lovell, 2003; NRC, 2011). However daily feeding frequencies change depending on several factors including fish species, size, water temperature, diet nutrient concentrations, farm management and fish health.

A previous study in whitefish (Coregonus lavaretus) showed that fish showed an increase in stomach capacity when meal frequency was reduced (Känkänen and Pirhonen, 2009). A similar adaptive mechanism in the gastric organs in response to restricted feeding schedules were also reported for flatfishes including turbot (Flowerdew and Grove, 1979; Jobling 1982). Anatomically, turbot has large mouth, therefore they can feed on macrofauna at a quite earlier life stage in the nature compared with other flatfish such as flounder, Platichthys flesus (Aarnio et al., 1996). They have also large esophagus and stomach allowing to ingest large preys (Aarnio et al., 1996). Reflection of these features to aquaculture conditions is that turbot can be fed less frequently and hence a substantial feeding related costs can be saved. Former studies in turbot weighing between 10 and $130 \mathrm{~g}$ showed that feeding two times a day was better than either one and three times a day or every other day and every two-day (Burel et al., 2000; Türker, 2006). Similarly, juvenile turbot with about $60 \mathrm{~g}$ weight showed best growth performance when fed twice a day 7 days a week, but when the number of feeding days reduced down to 4 days a week, the performance was inversely affected (Blanquet and Oliva-Teles, 2010). On the other hand, Aydin et al. (2011) reported that once a day feeding can be sufficient to sustain good growth in turbot with initial weights of 24 and $39 \mathrm{~g}$ both a satiation and restricted feeding conditions respectively. Apparently, optimum feeding frequency in growing turbot is still controversial. Therefore, the present study was planned to determine the effects of various feeding days, feeding frequency and starvation on growth and feed utilization in turbot.

\section{MATERIAL and METHODS}

\section{Experimental design}

The experiment was carried out at the Beymelek Unit of Mediterranean Fisheries Research Production and Training Institute, Antalya, Turkey. Juvenile turbot were selected from a $30 \mathrm{~m}^{3}$ rearing tank with water about $30 \mathrm{~m}^{3}$. Forty fish were randomly allocated to each of 18 tanks $(1.1 \times 1.1 \times 0.5 \mathrm{~m})$ and acclimated for two weeks prior to commencement of the study. During the adaptation period, fish were fed a commercial diet (Çamlı Yem, İzmir, Turkey) with 50\% protein and $16 \%$ lipid. The initial average weight was $110.3 \pm 0.5 \mathrm{~g}(\mathrm{n}=18)$. Brackish water was supplied to each tank at a flow rate of 5.4 $\mathrm{L} / \mathrm{min}$. Supplemental air from an air-blower was provided to each tank. Experimental system was an indoor system allowing natural light to enter. Fish were subjected to natural photoperiod between 10.5-11 h light and 13-13.5 h dark over the study period. A commercial diet (6 mm pellet diameter) containing $55 \%$ protein and $12 \%$ lipid was offered to fish at an apparent satiation in each meal. Water parameters such as temperature, dissolved oxygen, $\mathrm{pH}$ and salinity were daily monitored from selected four tanks with a hand DO meter and $\mathrm{pH}$ meter (YSI Model 55 and 63, YSI Inc., Yellowsprings, OH, USA) respectively. Average temperature, dissolved oxygen, $\mathrm{pH}$ and salinity values were $17.63 \pm 0.05{ }^{\circ} \mathrm{C}, 5.66 \pm 0.10 \mathrm{mg} / \mathrm{L}, 7.32 \pm 0.02$ and $7.20 \pm 0.02 \mathrm{ppt}$, respectively. During the study, fish were collectively weighed at the beginning and final after about one-day starvation period.

Six experimental treatments were tried in triplicate groups of fish. An explanatory overview of the treatments is given in Table 1 . 
Table 1. Feeding programs used in the experiment

\begin{tabular}{ccl}
\hline \hline Treatment no & Abbreviation & Explanation \\
\hline 1 & $7: 0_{(2)}$ & Everyday feeding : no starvation (twice a day) \\
2 & $6: 1_{(1)}$ & 6 days feeding : one day starvation (once a day) \\
3 & $6: 1_{(2)}$ & 6 days feeding : one day starvation (twice a day) \\
4 & $1: 1_{(2)}$ & 1 day feeding : one day starvation (twice a day) \\
5 & $1: 2_{(2)}$ & 1 day feeding : two days starvation (twice a day) \\
6 & $2: 1_{(2)}$ & 2 days feeding : one day starvation (twice a day) \\
\hline \hline
\end{tabular}

\section{Calculations}

Voluntary Feed Intake (VFI g/kg MBW / day, feeding day $\left(\mathrm{WFI}_{\mathrm{fd}}\right)$ or meal $\left.\left(\mathrm{VFI}_{\mathrm{m}}\right)\right)=($ dry matter intake / $\mathrm{MBW}^{0.8}$ ) / day (Van der Meer et al., 1997)

Metabolic Body Weight $\left(\mathrm{MBW}^{0.8}\right)=($ Geometric mean of initial weight (IW) and final weight $(\mathrm{FW}))^{0.8}$ (Saravanan et al., 2012)

Feed Conversion Efficiency (FCE) = weight gain / dry matter intake (Van der Meer et al., 1997)

Daily Growth Coefficient $(\mathrm{DGC})=\left[\left(\mathrm{FW}^{1 / 3}-\mathrm{IW}^{1 / 3}\right) /\right.$ day $] \times 100($ Saravanan et al., 2012$)$

\section{Statistical analysis}

Normality and homogeneity of the data were checked by Shapiro-Wilk W Test (Shapiro and Wilk, 1965) and Bartlett's test (Bartlett, 1937), respectively. One-way analysis of variance (ANOVA) and then Tukey post hoc test were used to detect the significant differences between the treatments. A significance level of $\mathrm{P}<0.05$ was used unless otherwise stated. Relationships between VFI and DGC, number of feeding day or meal and $\mathrm{WFI}_{\mathrm{fd}}$ or $\mathrm{WFI}_{\mathrm{m}}$ were checked by a linear regression. A Statistical package JMP v.8.0 for Windows was used for all statistical analyses. Relationship between number of daily meals and DGC was also checked using nonlinear models (broken line and quadratic broken line models) to estimate minimum meal number requirements of turbot weighing 100 and $175 \mathrm{~g}$. The models were run in Graphpad Prism for Windows (GraphPad Software, San Diego, CA, USA). The optimum daily meal number were defined based on the model fitting best in terms of the residual sum of squares.

\section{RESULTS and DISCUSSION}

In the present study, we changed feeding frequencies at a satiation level by mainly altering feeding days except 6:1 $1_{(1)}$ where only single feeding a day was made. This design resulted in 14-41 feeding days and 28-82 meals over the study period (Table 2). Fish fed varying feeding regimens had significantly different growth rates; i.e. particularly those on $7: 0_{(2)}$ and $6: 1_{(2)}$ performed significantly better than those on $1: 2_{(2)}(\mathrm{p}<0.05)$ in terms of DGC. The differences in growth rate actually were a reflection, at large extend, of amount of food consumed (Table 2 and Figure 1). Fish fed more frequently consumed more feed and individuals on 7:0 $0_{(2)}, 6: 1_{(2)}$ and $2: 1_{(2)}$ had significantly higher VFI than those on $1: 2_{(2)}$. This is consistent with previous observations in turbot by Blanquet and OlivaTeles (2010) and Türker (2006). In the present experiment, maximum daily feeding frequency was set at 2 times. We did not exceed this level since Burel et al. (2000) observed that delivering feed twice or thrice a day did not significantly change feed intake of turbot. 
Table 2. Growth, feed utilization and feed intake of turbot fed varying frequencies over 6 weeks

\begin{tabular}{lllllll}
\hline \hline & $\mathbf{7 : 0}_{(2)}$ & $\mathbf{6 : 1 _ { ( 1 ) }}$ & $\mathbf{6 : 1 _ { ( 2 ) }}$ & $\mathbf{1 : 1}_{(2)}$ & $\mathbf{1 : 2}_{(2)}$ & $\mathbf{2 : 1}_{(2)}$ \\
\hline Number of Feeding Days & 41 & 36 & 36 & 21 & 14 & 28 \\
Total Number of Meals & 82 & 36 & 72 & 42 & 28 & 56 \\
IW & $109.9 \pm 0.3$ & $109.9 \pm 0.4$ & $109.9 \pm 0.3$ & $109.8 \pm 0.0$ & $109.8 \pm 0.2$ & $112.4 \pm 2.7$ \\
FW & $172.7 \pm 1.2^{\mathrm{ab}}$ & $170.5 \pm 3.4^{\mathrm{ab}}$ & $175.0 \pm 5.9^{\mathrm{a}}$ & $158.7 \pm 3.2^{\mathrm{ab}}$ & $154.0 \pm 4.6^{\mathrm{b}}$ & $174.5 \pm 5.3^{\mathrm{a}}$ \\
DGC & $1.81 \pm 0.02^{\mathrm{a}}$ & $1.75 \pm 0.08^{\mathrm{ab}}$ & $1.86 \pm 0.15^{\mathrm{a}}$ & $1.46 \pm 0.08^{\mathrm{ab}}$ & $1.33 \pm 0.13^{\mathrm{b}}$ & $1.77 \pm 0.07^{\mathrm{ab}}$ \\
Feed intake (g/fish) & $49.67 \pm 1.13^{\mathrm{ab}}$ & $45.27 \pm 1.27^{\mathrm{ab}}$ & $51.37 \pm 5.07^{\mathrm{a}}$ & $39.73 \pm 3.34^{\mathrm{ab}}$ & $33.73 \pm 1.19^{\mathrm{b}}$ & $48.90 \pm 2.54^{\mathrm{a}}$ \\
VFI (g/kg MBW/day) & $5.91 \pm 0.13^{\mathrm{a}}$ & $5.42 \pm 0.20^{\mathrm{ab}}$ & $6.07 \pm 0.52^{\mathrm{a}}$ & $4.89 \pm 0.37^{\mathrm{ab}}$ & $4.21 \pm 0.16^{\mathrm{b}}$ & $5.74 \pm 0.20^{\mathrm{a}}$ \\
VFI (g/kg MBW/meal) & $2.96 \pm 0.06^{\mathrm{d}}$ & $6.17 \pm 0.23^{\mathrm{a}}$ & $3.46 \pm 0.30^{\mathrm{cd}}$ & $4.77 \pm 0.36^{\mathrm{bc}}$ & $6.16 \pm 0.24^{\mathrm{a}}$ & $4.20 \pm 0.14^{\mathrm{bc}}$ \\
VFI (g/kg MBW/feeding day) & $5.91 \pm 0.13^{\mathrm{d}}$ & $6.17 \pm 0.23^{\mathrm{d}}$ & $6.92 \pm 0.59^{\mathrm{cd}}$ & $9.55 \pm 0.73^{\mathrm{b}}$ & $12.33 \pm 0.48^{\mathrm{a}}$ & $8.41 \pm 0.29^{\mathrm{bc}}$ \\
FCE & $1.27 \pm 0.03$ & $1.35 \pm 0.11$ & $1.27 \pm 0.04$ & $1.26 \pm 0.02$ & $1.29 \pm 0.13$ & $1.25 \pm 0.04$ \\
\hline \hline
\end{tabular}

For treatment codes, please see Table 1.

Data are given as means \pm standard error of mean. Values at the same row with different superscripts are significantly different $(\mathrm{P}<0.05)$. IW: Initial weight, FW: Final weight, DGC: Daily growth coefficient, VFI: Voluntary feed intake, MBW: Metabolic body weight, FCE: Feed conversion efficiency

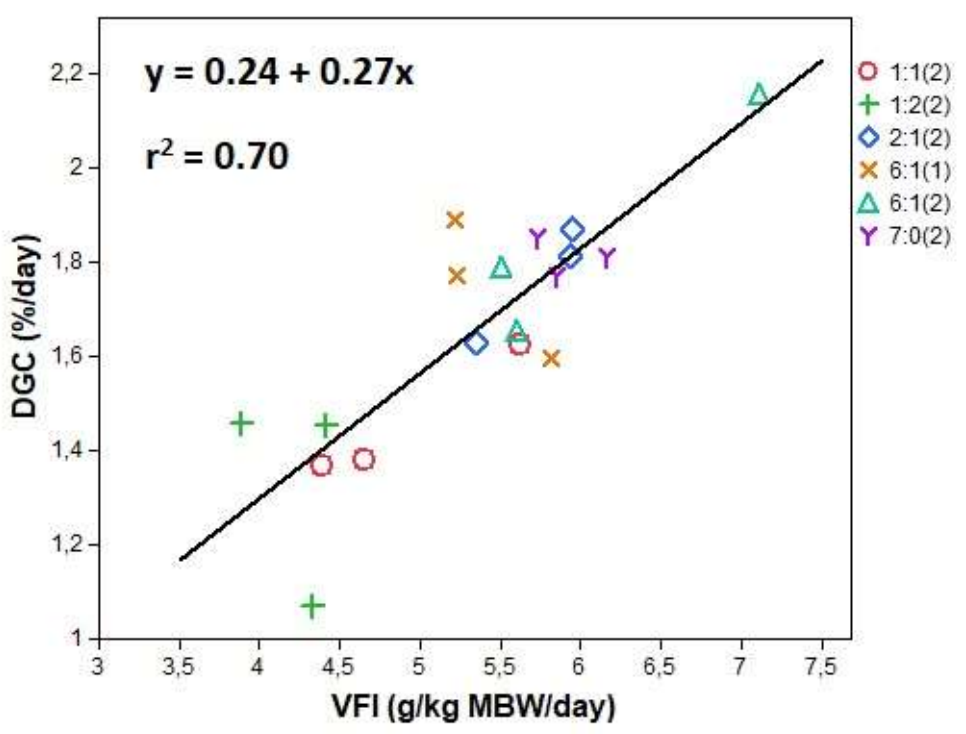

Figure 1. Relationship between VFI (voluntary feed intake) and DGC (daily growth coefficient) in turbot fed different feeding frequencies. DGC $(\% /$ day $)=0,24+0,27 * \mathrm{VFI}(\mathrm{g} / \mathrm{kg} \mathrm{MBW} /$ day $)$. MBW: Metabolic body weight

When VFI is calculated based on number of feeding days over the study period, the highest consumption was observed in fish on 1:2 $2_{(2)}$, followed by those on $1: 1_{(2)}$. More or less a similar trend was observed in $\mathrm{WFI}_{\mathrm{m}}$ where fish on $6: 1_{(1)}$ and $1: 2_{(2)}$ had significantly higher VFI than the others $(\mathrm{p}<0.05)$. Both $\mathrm{WFI}_{\mathrm{fd}}$ and $\mathrm{WFI}_{\mathrm{m}}$ had strong inverse relationships with feeding days $\left(\mathrm{n}=18, \mathrm{r}^{2}=0.89\right)$ and number of meals $\left(n=18, r^{2}=0.87\right)$, respectively (Figure 2$)$, meaning that fish responded to a decrease in feed abundance with an increase of feed intake. This behavior is well harmony with previous findings summarized by Carter et al. (2001), who underlined that fish respond to feed restriction by either reducing feeding frequency or abundancy with an increase in meal size. Decreasing meal numbers results in a size increase of gastro intestinal tract in fish (Flowerdew and Grove, 1979; Grove et al., 1985; Jobling, 1982; Carter et al., 2001). As mentioned in introduction section, turbot has large mouth and stomach, and thereby they can ingest large meals at once (Aarnio et al., 1996), which was also confirmed in experimental conditions by Flowerdew and Grove (1979) and Grove et al. (1985). This suggests that turbot has an intrinsic ability to compensate lower feeding frequencies in farm conditions. However, consumption of large meals at limited feeding events did not bring a comparable growth in fish to those fed more frequently in the present study. Indeed, a restricted feeding regimens (once every other day) in plaice (Pleuronectes platessa) resulted in an 
increased food intake in each feeding event due to enlarged stomach, but these fish lagged behind those fed continuously in terms of growth rate (Jobling, 1982). Another issue that should be underlined in terms of varying feeding rates in turbot is related to relationship between gastric emptying rate and return of appetite. Return of appetite is thought to be closely associated with stomach fullness (Grove et al., 1985; Alanärä et al., 2002). Gastric emptying rate in fish is affected by a number factors including fish size, water temperature, meal size, feeding rate, feed type (dry or wet), ingredient particle size and feed nutrient concentrations (Flowerdew and Grove, 1979; Grove et al., 1985; Alanärä et al., 2002). It can be concluded in the present study that more frequently fed turbot appeared to have fuller stomach and therefore they consumed less amounts of feed intake in each feeding meal (Figure 2).

There should be a limit which farmers can reduce feeding frequencies in practice. To estimate minimum number of daily meal required for maximum DGC, we used linear and quadratic broken line models and they generated residual sum of squares of 0.6672 and 0.6593 respectively, suggesting that the latter should be used. The quadratic model estimated the daily meal number as 1.756 (Figure 3 ). This level is almost equal to feeding twice a day for 6 days a week. Therefore, our findings in terms of number of daily meals are consistent, to a large degree, with those of Burel et al. (2000), Türker (2006) and Blanquet and Oliva-Teles (2010), who recommended feeding twice a day in juvenile turbot. However, there are also conflicting findings in the literature; for instance, feeding once a day was preferred at both restricted and satiation feedings by Aydin et al. (2011).
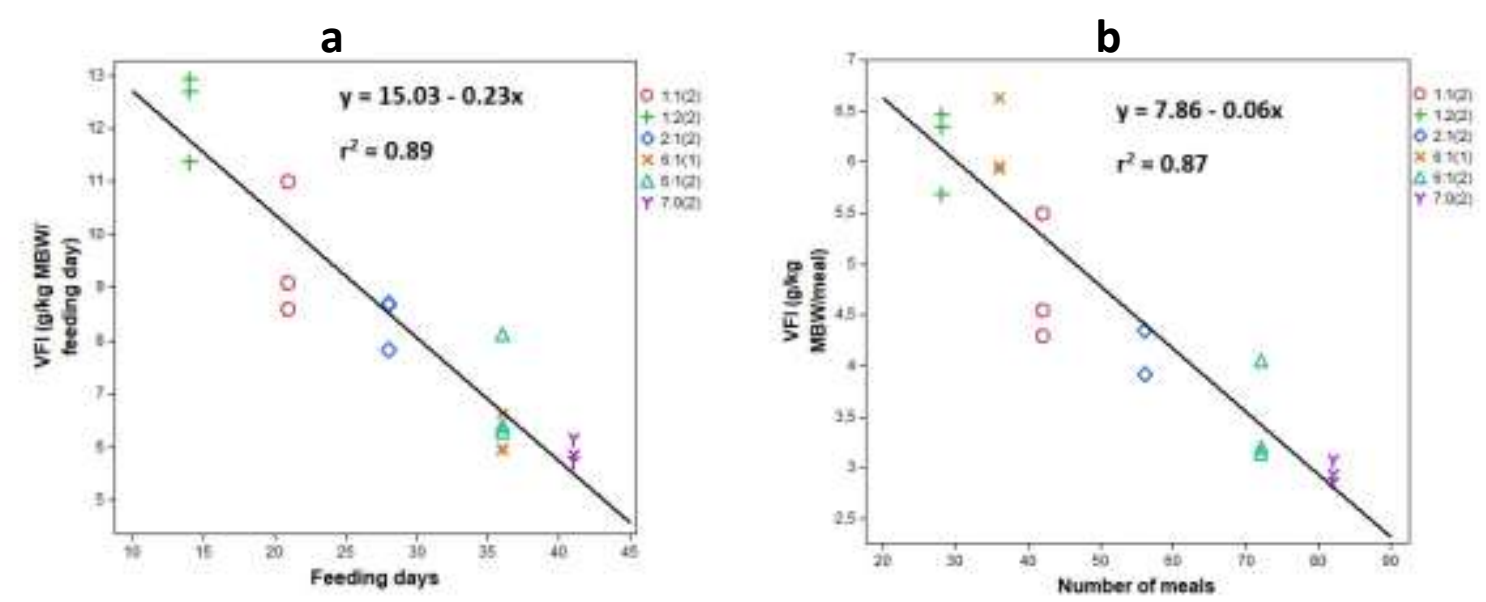

Figure 2. Relationship between number of feeding days and voluntary feed intake per feeding day: VFI (g/kg $\mathrm{MBW} /$ feeding day $)=15.03-0.23$ (Feeding days) (a) and meal: VFI $(\mathrm{g} / \mathrm{kg} \mathrm{MBW} / \mathrm{meal})=7.86-0.062$ (Number of meals) (b). VFI: Voluntary feed intake, MBW: Metabolic body weight

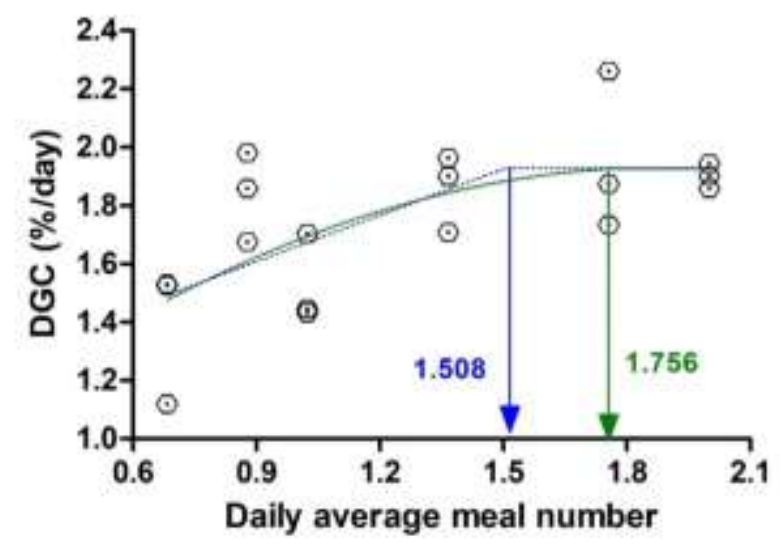

Figure 3. Relationship between daily average meal number and DGC (\%/day); blue: linear broken line model, green: quadratic broken line. DGC: Daily growth coefficient. 
Since the effect of various feeding frequencies on FCE of turbot was not significant in the current study, the observed growth differences among the treatments were due to variations in amount of feed consumptions, which are consistent with the observations of Grove et al. (1985), who reported comparable protein and energy assimilation rates in turbot regardless of feeding rates. However, some authors found that feed restriction improved FCE in turbot (Van Ham et al., 2003; Blanquet and OlivaTeles, 2010). The discrepancies between our study and others could be due to differences in method of feed restrictions, i.e. we restricted amounts of feed by changing the frequencies and the former authors did by reducing feeding rates. This point is important because fish show a greater feed consumption after a period of food deprivation without an improvement of FCE (Nikki et al., 2004; Sevgili et al., 2013). However, a dietary restriction with feeding rate results in better FCE in fish including turbot (Van Ham et al., 2003; Eroldoğan et al., 2004; Blanquet and Oliva-Teles, 2010).

Although we did not record the individual weights of fish, juvenile Colossoma macropomum showed a greater size heterogeneity when fed less frequently due to development of hierarchy (Van der Meer et al., 1997), which should be taken into consideration in feeding management of turbot as well.

Briefly although various treatments showed similar growth rates at the end of the experiment, quadratic broken line method estimated a daily meal number of 1.756, tantamount to 6 days feeding a week with twice a day, as an optimum feeding rate for maximum growth of turbot weighing about 140 g.

Acknowledgments: This study was supported by the Japan International Cooperation Agency and General Directorate of Agricultural Production, Turkey. Senior scientist G. Nezaki and other project members are gratefully acknowledged for their valuable contributions during the study.

\section{REFERENCES}

Aarnio, K., Bonsdorff, E., \& Rosenback, N. (1996). Food and feeding habits of juvenile flounder Platichthys flesus (L.), abd turbot Scophthalmus maximus L. in the åland archipelago, northern Baltic Sea. Journal of Sea Research, 36, 311-320.

Alanärä, A., Kadri, S., \& Paspatis, M. (2001). Feeding management. In Food intake in fish (Houlihan, D. et al. eds.), pp. 332-353. Blackwell Science, Oxford, UK.

Aydin, I., Küçük, E., Sahin, T., \& Kolotoglu, L. (2011). The effect of feeding frequency and feeding rate on growth performance of juvenile black sea turbot (Psetta maxima, Linneaus, 1758). Journal of Fisheries Sciences, 5(1), 35-42.

Bartlett M. S. (1937). Properties of sufficiency and statistical tests. Proceedings of the Royal Society of London, Series A, 160, 268-282.

Blanquet, I., \& Oliva-Teles, A. (2010). Effect of feed restriction on the growth performance of turbot (Scophthalmus maximus L.) juveniles under commercial rearing conditions. Aquaculture research, 41, $1255-1260$

Burel, C., Boujard, T., Kaushik, S.J., Boeuf, G., Van Der Geyten, S., Mol, K.A., Kühn, E.R., Quinsac, A., Krouti, M., \& Ribaillier, D. (2000). Potential of plant-protein sources as fish meal substitutes in diets for turbot (Psetta maxima): growth, nutrient utilisation and thyroid status. Aquaculture, 188, 363-382.

Carter, C., Houlihan, D., Kiessling, A., Médale, F., \& Jobling, M. (2001). Physiological effects of feeding In Food intake in fish (Houlihan, D. et al. eds.), pp. 297-331. Blackwell Scientific, Oxford, UK.

Eroldoğan, O., Kumlu, M., \& Aktaş, M. (2004). Optimum feeding rates for European sea bass Dicentrarchus labrax L. reared in seawater and freshwater. Aquaculture, 231, 501-515.

Flowerdew, M. W., \& Grove, D. J. (1979). Some observations of the effects of body weight, temperature, meal size and quality on gastric emptying time in the turbot, Scophthalmus maximus (L.) using radiography. Journal of Fish Biology, 14, 229-238.

Grove, D. J., Moctezuma, M. A., Flett, H. R. J., Foott, J. S., Watson, T., \& Flowerdew, M. W. (1985). Gastric emptying and the return of appetite in juvenile turbot, Scophthalmus maximus L., fed on artificial diets. Journal of Fish Biology, 26, 339-354.

Jobling, M. (1982). Some observations on the effects of feeding frequency on the food intake and growth of plaice, Pleuronectes platessa L. Journal of Fish Biology, 20, 431-444.

Känkänen, M., \& Pirhonen, J., 2009. The effect of intermittent feeding on feed intake and compensatory growth of whitefish Coregonus lavaretus L. Aquaculture. 288, 92-97.

Lovell, R.T. (2003). Diet and Fish Husbandry In Fish Nutrition (Third Edition) (Halver, J.E. \& Hardy, R.W. eds.), pp. 703-754. Academic Press, San Diego. 
Nikki, J., Pirhonen, J., Jobling, M., \& Karjalainen, J. (2004). Compensatory growth in juvenile rainbow trout, Oncorhynchus mykiss (Walbaum), held individually. Aquaculture, 235, 285-296.

NRC (2011). NRC. Nutrient requirements of fish and shrimp. Washington, DC: National Research Council of the National Academies.

Saravanan, S., Schrama, J. W., Figueiredo-Silva, A. C., Kaushik, S. J., Verreth, J. A., \& Geurden, I. (2012). Constraints on energy intake in fish: the link between diet composition, energy metabolism, and energy intake in rainbow trout. Plos One, 7(4), e34743.

Sevgili, H., Hoşsu, B., Emre, Y., \& Kanyılmaz, M. (2013). Effect of various lengths of single phase starvation on compensatory growth in rainbow trout under summer conditions (Oncorhynchus mykiss). Turkish Journal of Fisheries and Aquatic Sciences, 13, 465-477.

Shapiro, S. S., \& Wilk, M. B. (1965). An analysis of variance test for normality (complete samples). Biometrika, 52, 591-611.

Türker, A. (2006). Effects of feeding frequency on growth, feed consumption, and body composition in juvenile turbot (Psetta maxima Linnaeus, 1758) at low temperature. Turkish Journal of Veterinary and Animal Sciences, 30, 251-256.

Van der Meer, M., Herwaarden, H.V., \& Verdegem, M. (1997). Effect of number of meals and frequency of feeding on voluntary feed intake of Colossoma macropomum (Cuvier). Aquaculture Research, 28, 419432.

Van Ham, E.H., Berntssen, M.H., Imsland, A.K., Parpoura, A.C., Bonga, S.E.W., \& Stefansson, S.O. (2003). The influence of temperature and ration on growth, feed conversion, body composition and nutrient retention of juvenile turbot (Scophthalmus maximus). Aquaculture, 217, 547-558. 